\title{
2nd Generation PFBC Systems R\&D \\ Phase 2 and Phase 3
}

Monthly Technical Report

Peroting Period Start Date: 12/01/1999End Date: 12/31/1999

Author: Archie Robertson

Report Issue Date: 03/17/2000

DE-AC21-86MC21023

Foster Wheeler Development Corporation

12 Peach Tree Hill Road

Livingston, NJ 07039 
"This report was prepared as an account of work sponsored by an agency of the United States Government. Neither the United States Government nor any agency thereof, nor any of their employees, makes any warranty, express or implied, or assumes any legal liability or responsibility for the accuracy, completeness, or usefulness of any information, apparatus, product, or process disclosed, or represents that its use would not infringe upon privately owned rights. Reference herein to any specific commercial product, process, or service by trade name, trademark, manufacturer, or otherwise does not necessarily constitute or imply its endorsement by the United States Government or any agency thereof. The views and opinions of authors expressed herein do not necessarily state or reflect those of the United States Government or any agency thereof." 


\section{TECHNICAL PROGRESS REPORT NUMBER 21023R50 \\ FOR MONTH 141 (DECEMBER 1999) -- PHASE 2}

No work was performed; the two remaining Multi Annular Swirl Burner test campaigns are on hold pending selection of a new test facility (replacement for the shut down UTSI burner test facility) and identification of associated testing costs. 
"This report was prepared as an account of work sponsored by an agency of the United States Government. Neither the United States Government nor any agency thereof, nor any of their employees, makes any warranty, express or implied, or assumes any legal liability or responsibility for the accuracy, completeness, or usefulness of any information, apparatus, product, or process disclosed, or represents that its use would not infringe upon privately owned rights. Reference herein to any specific commercial product, process, or service by trade name, trademark, manufacturer, or otherwise does not necessarily constitute or imply its endorsement by the United States Government or any agency thereof. The views and opinions of authors expressed herein do not necessarily state or reflect those of the United States Government or any agency thereof." 


\title{
TECHNICAL PROGRESS REPORT NUMBER 21023R51 \\ FOR MONTH 110 (DECEMBER 1999) -- PHASE 3
}

\author{
Commercial Plant Design Update
}

\section{Introduction}

The Second-Generation PFB Combustion Plant conceptual design prepared in 1987 is being updated to reflect the benefit of pilot plant test data and the latest advances in gas turbine technology. The updated plant is being designed to operate with 95 percent sulfur capture and a single Siemens Westinghouse (SW) 501G gas turbine. Using carbonizer and gas turbine data generated by Foster Wheeler (FW) and SW respectively, Parsons Energy and Chemicals Group prepared preliminary plant heat and materials based on carbonizer operating temperatures of 1700 and $1800 \mathrm{EF}$ and found the former to yield the higher plant efficiency.

As a result, $1700 \mathrm{EF}$ has been selected as the preferred operating condition for the carbonizer. The previous first cut plant heat and material balance was refined and it predicts a $47.7 \%$ plant efficiency (HHV) with a net power output of $421.1 \mathrm{MWe}$. The latter includes a plant auxiliary load estimated to be $23.5 \mathrm{MWe}$ or $5.26 \%$ of the gross plant power and a transformer loss of $1.5 \mathrm{MWe}$. Coal drying is through natural gas combustion, and the thermal energy input of the natural gas has also been included in the heat rate calculation. Figure 1 presents the plant preliminary full load heat and material balance. In this arrangement, evaporation and primary steam superheating tube surfaces are placed in both the pressurized circulating fluidized bed boiler (PCFB) and the gas turbine heat recovery steam generator (HRSG). The superheated steam from these units is mixed and then heated to 1050EF in the PCFB finishing superheater. With regard to steam reheating, the primary stage is located at the front of the HRSG and the final stage is located in the PCFB. Although this circuitry arrangement appears workable at full load, minimum load must be checked next to see if rearrangement is needed. Plant start up and load following discussions indicated that below about 15 percent gas turbine load, the latter would transition from steam to air cooling.

\section{Work Performed in December 1999}

Keeping the gas turbine at 15 percent load to avoid switching from steam to air cooling, a heat and material balance was prepared that indicates a net plant output of $97 \mathrm{MWe}$ or 23 percent load. The balance presented in Fig. 2 shows gas turbine and steam turbine outputs of 35.9 and $79.7 \mathrm{MWe}$ or 15 and 39 percent of full load respectively. At this condition the gas turbine inlet guide vanes are closed (air flow is reduced by 27 percent) and the gas turbine exhaust temperature is reduced from $1138 \mathrm{EF}$ down to $741 \mathrm{EF}$. The steam turbine has been set for fixed pressure operation, and with the main steam flow reduced to $4,552,800 \mathrm{lb} / \mathrm{h}$ (40 percent of full load) superheat and reheat temperatures are shown as being maintained at 1050EF with carbonizer syngas and PCFB flue gas volumetric flow rates at 12 and 127 percent of full load values. The resulting carbonizer velocity is too low and will necessitate a revision to this operating condition. 
As the reporting period ended, work was begun to determine plant performance at intermediate load points of about 50 and 75 percent load. These new balances, together with those for 100 and 23 percent load, will form a theoretical operating map; once the map is completed, efforts will begin to establish component physical arrangements and dimensions which in turn will determine the part load capabilities of the plant. 


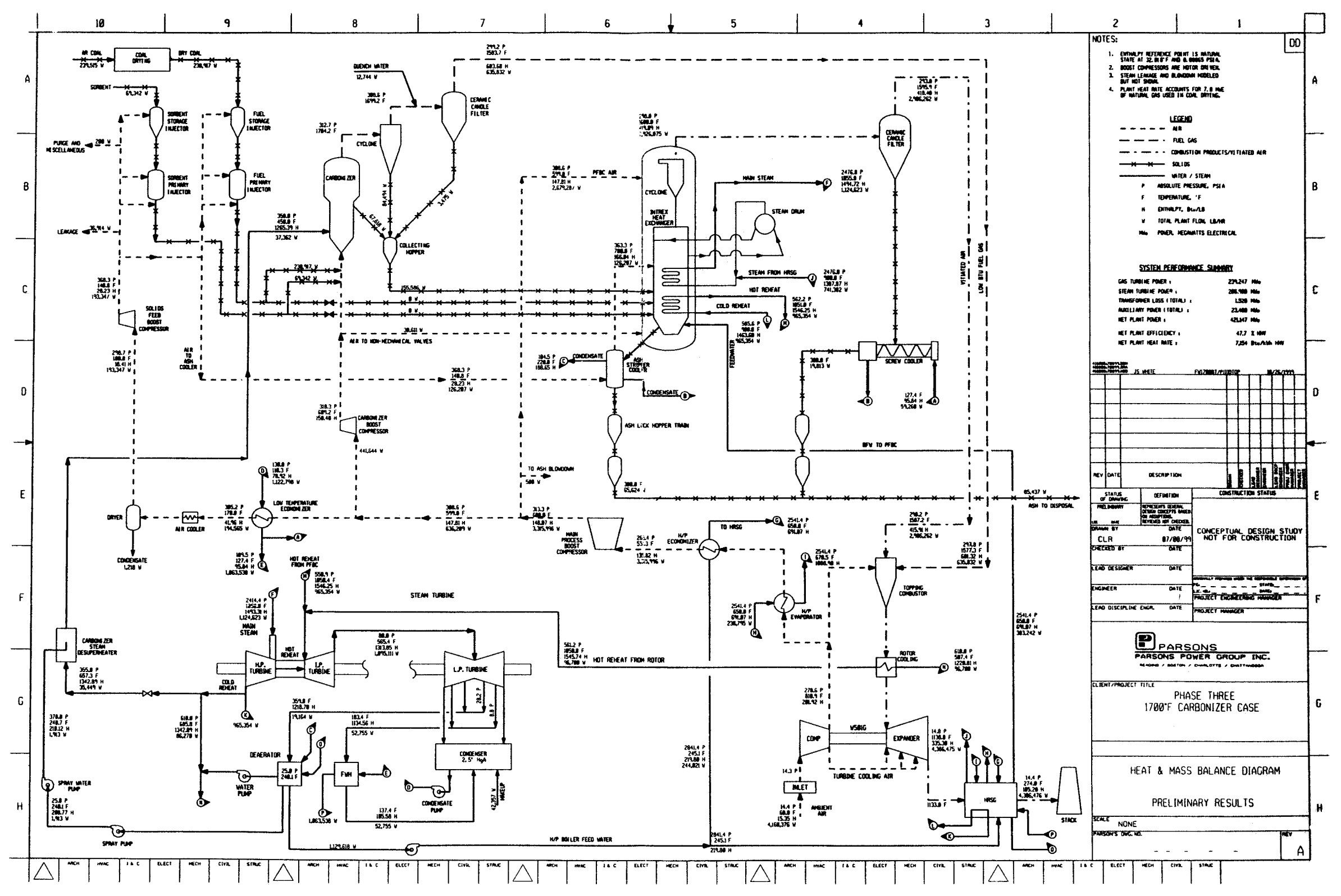

Figure 1 


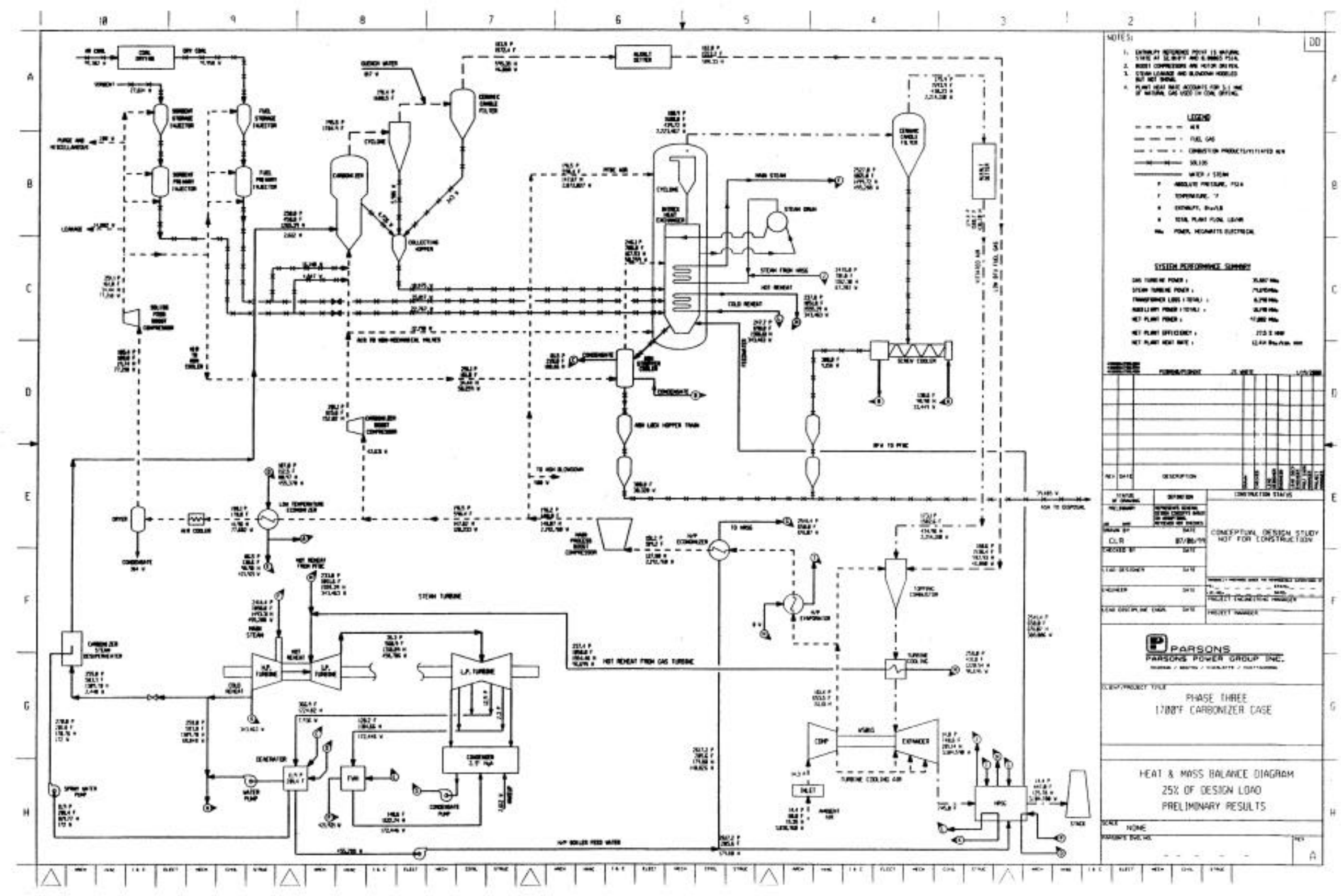

Figure 2 